\title{
Signaling Gradients during Paraxial Mesoderm Development
}

\author{
Alexander Aulehla ${ }^{1}$ and Olivier Pourquiée ${ }^{1,2,3}$ \\ ${ }^{1}$ Stowers Institute for Medical Research, Kansas City, Missouri 64110 \\ ${ }^{2}$ Howard Hughes Medical Institute, Kansas City, Missouri 64110 \\ ${ }^{3}$ Department of Anatomy \& Cell Biology, The University of Kansas School of Medicine, \\ Kansas City, Kansas 66103 \\ Correspondence: olp@stowers.org
}

\begin{abstract}
The sequential formation of somites along the anterior-posterior axis is under control of multiple signaling gradients involving the Wnt, FGF, and retinoic acid (RA) pathways. These pathways show graded distribution of signaling activity within the paraxial mesoderm of vertebrate embryos. Although Wnt and FGF signaling show highest activity in the posterior, unsegmented paraxial mesoderm (presomitic mesoderm [PSM]), RA signaling establishes a countergradient with the highest activity in the somites. The generation of these graded activities relies both on classical source-sink mechanisms (for RA signaling) and on an RNA decay mechanism (for FGF signaling). Numerous studies reveal the tight interconnection among Wnt, FGF, and RA signaling in controlling paraxial mesoderm differentiation and in defining the somite-forming unit. In particular, the relationship to a molecular oscillator acting in somite precursors in the PSM — called the segmentation clock-has been recently addressed. These studies indicate that high levels of Wnt and FGF signaling are required for the segmentation clock activity. Furthermore, we discuss how these signaling gradients act in a dose-dependent manner in the progenitors of the paraxial mesoderm, partly by regulating cell movements during gastrulation. Finally, links between the process of axial specification of vertebral segments and Hox gene expression are discussed.
\end{abstract}

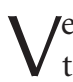
ertebrate embryonic development is characterized by a head-to-tail progression of differentiation. Anterior structures are developmentally advanced and initiate developmental programs first when compared to more posterior regions in the embryo. This is well illustrated during somitogenesis, when somites (the precursors of vertebrae) form periodically in an obvious head-to-tail sequence. In the vertebrate embryo, this arrangement of somites represents the first overt sign of a segmented body plan and plays a central role in subsequent body patterning. For instance, the metameric arrangement of somites determines the pattern of motor axon outgrowth and neural crest migration and therefore is responsible for the metameric arrangement of the peripheral nervous system (Keynes and Stern 1984; Rickmann et al. 1985; Bronner-Fraser 1986; Teillet et al. 1987). Somites are located within

Editors: James Briscoe, Peter Lawrence, and Jean-Paul Vincent

Additional Perspectives on Generation and Interpretation of Morphogen Gradients available at www.cshperspectives.org

Copyright (C) 2010 Cold Spring Harbor Laboratory Press; all rights reserved; doi: 10.1101/cshperspect.a000869

Cite this article as Cold Spring Harb Perspect Biol 2010;2:a000869 
the paraxial mesoderm, flanking both sides of the neural tube. In the posterior part of the embryo, the paraxial mesoderm is arranged as mesenchymal, still unsegmented tissue called the presomitic mesoderm (PSM). As new somites bud off from the anterior PSM, new cells enter the PSM posteriorly from a growth zone-called the tail bud-thus replenishing the PSM. Hence, in the anterior part of the embryo, somites form and begin to differentiate into various tissues (e.g., vertebrae, ribs, intercostal muscles, and dermis of the back and tendons), whereas in the posterior embryo the paraxial mesoderm remains unsegmented and undifferentiated (Christ and Ordahl 1995).

Remarkably, as cells enter the PSM from the tail bud, they retain their mesenchymal state for some time (approximately one to two cell divisions or 9-18 $\mathrm{h}$ in mouse and chicken embryos) before they are incorporated into an epithelial somite (Packard and Jacobson 1976; Tam 1981; Stern et al. 1988). In addition, cells located in the posterior PSM maintain an undifferentiated and pluripotent state. Accordingly, cells in the posterior (but not the anterior) PSM contribute to tissues other than somites, such as derivatives of the intermediate mesoderm (e.g., mesonephric tubules) and the lateral plate mesoderm (Stern et al. 1988). In addition, in all vertebrate species studied, oscillatory transcriptional activity of a subset of genes (cyclic genes) is found within the PSM. These oscillations are driven by a molecular oscillator, called the segmentation clock, which is thought to control the timing of somite formation (Palmeirim et al. 1997).

A mechanism must, therefore, be in place to maintain the undifferentiated state of cells in the posterior PSM and to control initiation of differentiation once cells reach the anterior PSM. This mechanism is currently thought to be based on a combinatorial gradient system in the PSM that involves the activity of the fibroblast growth factor (FGF), the Wnt/ $\beta$-catenin, and the retinoic acid (RA) signaling pathways (Dubrulle and Pourquié 2004a). The FGF (Dubrulle et al. 2001; Sawada et al. 2001; Dubrulle and Pourquié 2004b) and Wnt/ $\beta$-catenin signaling pathways (Aulehla et al.
2003; Aulehla et al. 2008) form a posterioranterior gradient, whereas the RA signaling pathway establishes an opposing gradient of activity (Diez del Corral et al. 2003; Moreno and Kintner 2004; Vermot and Pourquié 2005). Before we discuss how these gradients control the differentiation of PSM cells, we will describe what is known about how these gradients of activity are established in the PSM.

\section{MECHANISMS OF GRADIENT GENERATION IN THE PSM}

RA Signaling Activity Establishes an Anterior-Posterior Gradient via the Localized Expression of RA-Metabolizing Enzymes

Although RA cannot be visualized directly, its activity can be detected, for instance, in transgenic reporter mice that carry an RA signaling responsive element driving LacZ expression (RARE-LacZ) (Rossant et al. 1991). This reporter indicates that RA signaling activity is highest in the somites and anterior PSM, whereas it is absent in more posterior parts of the embryo, including the tail bud. The expression patterns of enzymes involved in RA metabolism provide an explanation for this activity distribution (Fig. 1). Raldh2, an RA-synthesizing enzyme, shows strongest expression in somites and the anterior PSM (Niederreither et al. 1997). In contrast, Cyp26A1, a cytochrome p450 enzyme involved in RA degradation (Fujii et al. 1997), is expressed in the tail bud (Sakai et al. 2001). Thus, it appears that RA activity, which has the ability to diffuse over long distances (Eichele and Thaller 1987), is spatially confined largely by the expression of synthesizing and degrading enzymes (Sakai et al. 2001; Niederreither and Dolle 2008). The establishment of the RA signaling gradient, therefore, conforms to the classical definition of a diffusible morphogen gradient and involves a source-sink mechanism (Gurdon and Bourillot 2001).

The FGF and Wnt Signaling Gradients Are Established via an mRNA Decay Mechanism

In contrast to the source-sink mechanism generating classical morphogen gradients, it 


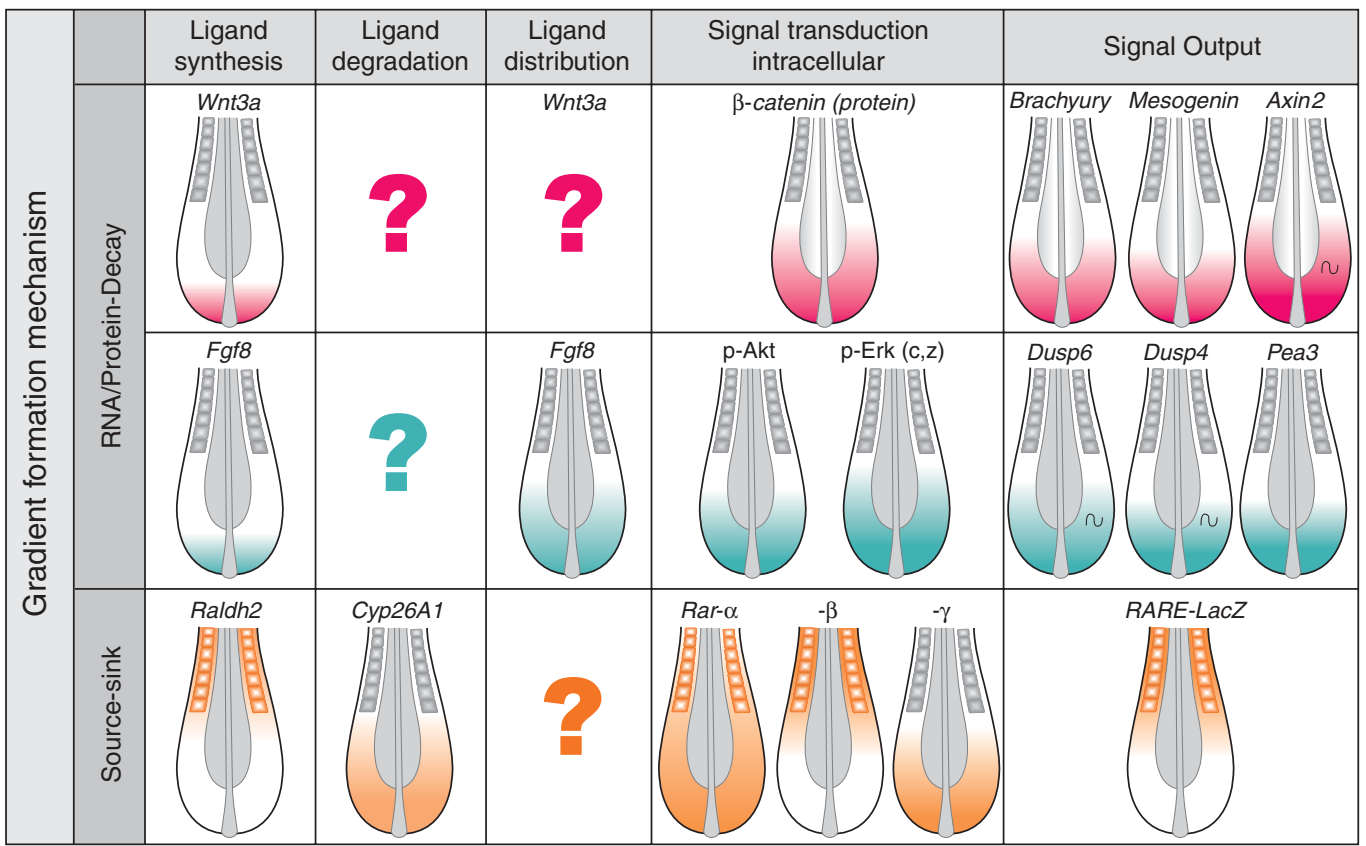

Figure 1. Scheme of signaling gradient system in the presomitic mesoderm (PSM) of mouse embryos. If not stated otherwise, illustrations reflect mRNA expression patterns in the PSM of mouse embryos. Additional sites of expression (e.g., somites, neural tube) are not shown. For Akt and Erk, the distribution of the activated, phosphorylated protein is shown (p-Akt, p-Erk). For Erk, these data derive from chicken (c) and zebrafish (z) embryos. For Axin2, Dusp6, and Dusp4, the graded expression is periodically down-regulated in the posterior PSM, as indicated by the oscillation symbol $(\sim)$.

has been shown that an Fgf8 protein gradient across the PSM could emerge via a distinct mechanism, based on mRNA decay (Dubrulle and Pourquié 2004b). Accordingly, although Fgfo mRNA can be found in a posterioranterior gradient within the PSM, the site of de novo Fgf8 transcription is actually confined to the tail bud region (Fig. 2). As cells leave the tail bud region and enter the PSM, Fgf8 mRNA production ceases and, thus, Fgf8 mRNA concentration will decay over time. As a result, a posterior-anterior $F g f 8$ mRNA gradient is established, which is then translated into an Fgf8 protein gradient (Dubrulle and Pourquié 2004b). On binding to Fgf receptor 1 (Fgfr1), which is the only Fgfr expressed in the PSM (Wahl et al. 2007), FGF signaling is mediated intracellularly by several distinct downstream pathways that include the mitogen-activated protein kinase (MAPK)/ extracellular signal-regulated kinase (Erk), and the phosphatidylinositol 3-kinase (PI3K) pathways (Bottcher and Niehrs 2005). In mouse embryos, the Fgf8 gradient correlates with a gradient of activated Akt, the kinase downstream of PI3K (Dubrulle and Pourquié 2004b), whereas in chicken and zebrafish embryos, a graded distribution of activated Erk protein is found in the PSM (Sawada et al. 2001; Delfini et al. 2005). The graded activity of Erk or Akt in chicken and mouse embryos, respectively, is thought to ultimately result in the graded activation of downstream targets—such as Dusp4 (Niwa et al. 2007), Dusp6 (Dequéant et al. 2006; Li et al. 2007), snaill (Dale et al. 2006), or Pea3 (Roehl and Nüsslein-Volhard 2001) all of which show the highest expression level in the posterior PSM.

This distinct mode of gradient formation was independently suggested to underlie the generation of a Wnt signaling gradient in the PSM (Aulehla et al. 2003). Here, Wnt3a 
A. Aulehla and O. Pourquié
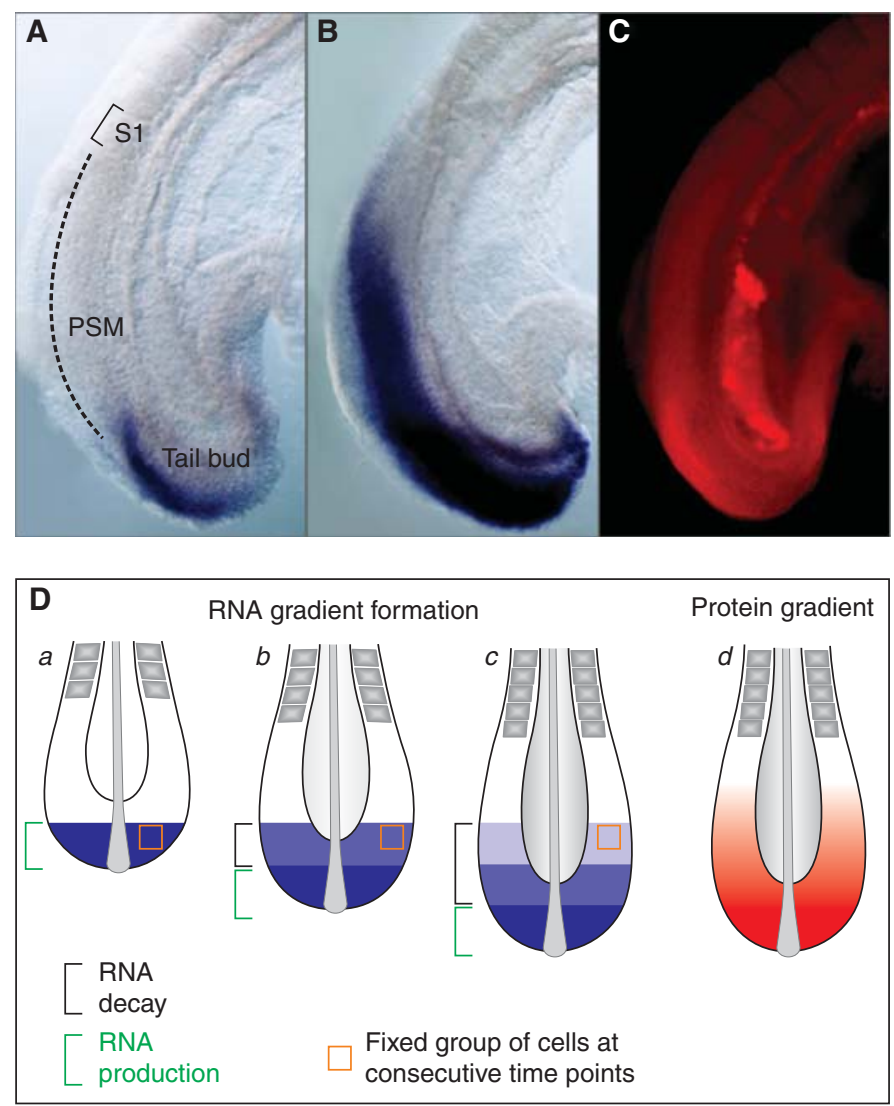

Figure 2. An RNA decay mechanism establishes the Fgf8 gradient within the PSM. $(A)$ In situ hybridization (ISH) for Fgf8 pre-mRNA using an intronic probe in a mouse embryo indicates that de novo transcription is localized to the tail bud region. (S1) last formed somite, (PSM) presomitic mesoderm. (B) ISH for mature Fgf8 mRNA shows a graded distribution within the PSM. (C) Immunofluorescent detection of Fgf8 shows a posterior-anterior protein gradient. $(D)$ Scheme of gradient formation using an RNA decay mechanism. In the temporal series $a-c$, a constant group of cells (orange square) and its Fgf 8 RNA expression characteristics are shown. In $a$, this group of cells is located in the posterior-most PSM and tail bud and hence shows de novo Fgf8 transcription. For simplicity, only de novo synthesized RNA is shown in $a$. At a later time point (b), the same group of cells is now located in the posterior one-third of PSM because of the posterior addition of cells during axis elongation. Fgf8 transcription in the PSM ceased, and as a consequence, Fgf8 mRNA decayed in comparison to the levels in the tail bud. At an even later time point $(c)$, this group of cells is located in the middle PSM, and again Fgf8 mRNA levels are further decreased. In consequence, Fgf8 mRNA levels are graded in the PSM. This mRNA gradient is translated into a posterior-anterior Fgf8 ligand gradient $(d)$.

mRNA — encoding a key ligand that activates the canonical Wnt/ $\beta$-catenin signaling pathway in the PSM (Takada et al. 1994; Greco et al. 1996; Yoshikawa et al. 1997; Yamaguchi et al. 1999; Aulehla et al. 2003; Nakaya et al. 2005; Dunty et al. 2008)—shows a confined expression in the most posterior PSM and tail bud (Fig. 3A). Logically, this prompted the proposal that as cells leave the tail bud region, Wnt3a de novo protein production ceases. Thus, comparable to the situation for Fgf8, it has been suggested that as cells leave the tail bud, Wnt3a protein levels will decrease and thereby establish a gradient of Wnt3a ligand availability (Aulehla et al. 2003; Aulehla and Herrmann 2004). However, because Wnt3a 
Signaling Gradients
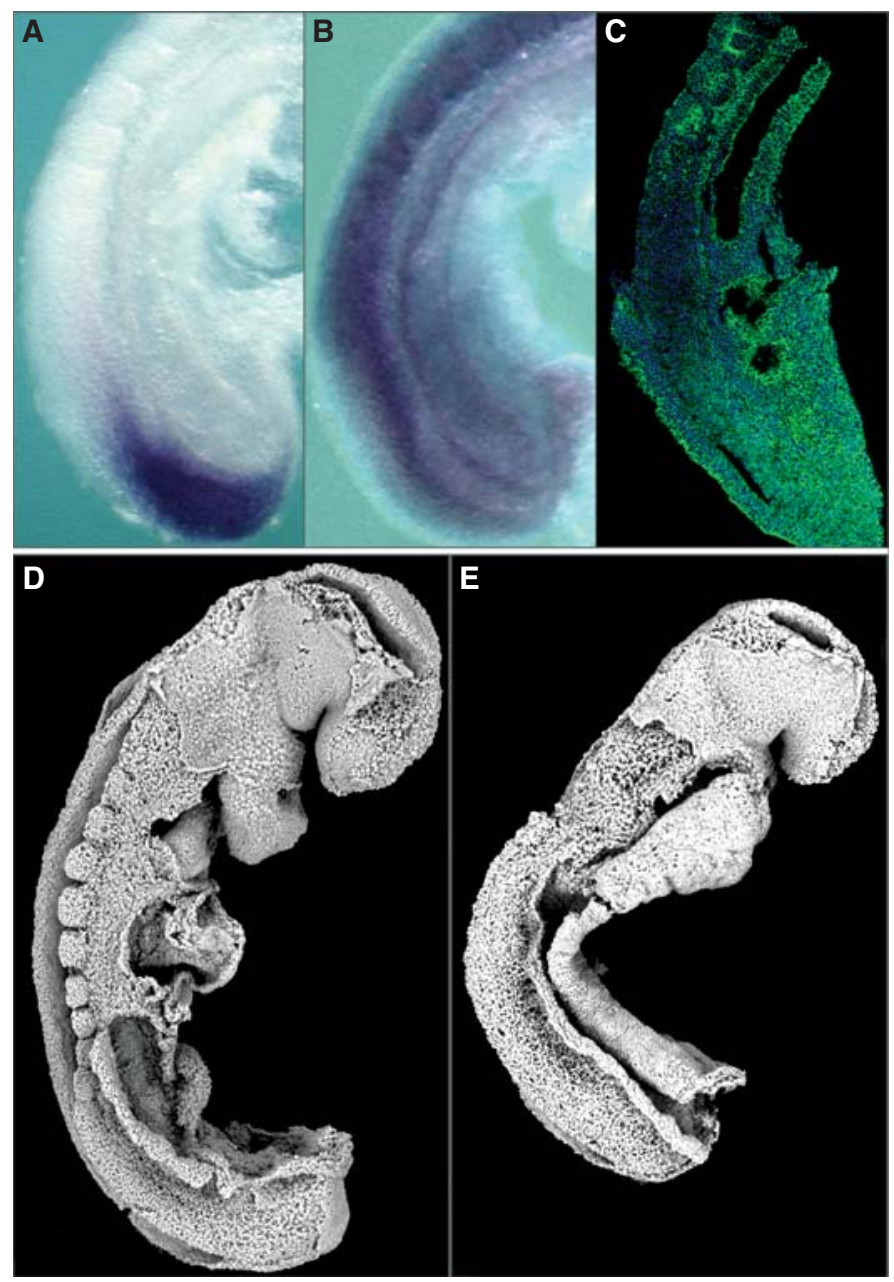

Figure 3. A $\beta$-catenin protein gradient controls PSM differentiation and somite formation. (A) ISH for Wnt3a mRNA in 9.5 days postcoitum $(\mathrm{dpc})$ mouse embryo shows site of localized ligand production in the posterior PSM/tail bud. (B) ISH for $\beta$-catenin mRNA shows ubiquitous expression in the PSM of mouse embryos. ( $C$ ) In contrast, $\beta$-catenin immunofluorescent detection (green) reveals a posterior-anterior nuclear protein gradient within the PSM. DAPI staining is shown in blue. (D) Scanning electron microscopy image of a control $9.0 \mathrm{dpc}$ mouse embryo showing the periodic arrangement of formed somites. (E) Scanning electron microscopy image of mutant embryo in which a stabilized isoform of $\beta$-catenin has been conditionally expressed in mesodermal cells. Note that disruption of the $\beta$-catenin protein gradient leads to an expanded, undifferentiated PSM and an absence of somite formation. In $D$ and $E$, the ectoderm was removed, which allows a direct view of the mesodermal layer.

has not been quantified or visualized in the PSM, only indirect evidence based on the expression patterns of downstream Wnt3a targets could be used to support this proposal. Intracellularly, a Wnt3a ligand gradient could consequently cause a graded stabilization of $\beta$-catenin, the key mediator of canonical Wnt signaling (Seidensticker and Behrens 2000; Nusse 2005). The mRNA of $\beta$-catenin shows a rather uniform expression in the PSM of mouse embryos (Fig. 3B) and, indeed, $\beta$ catenin is ubiquitously present as a component of the cadherin/catenin complex at the cell membrane in this tissue (Linask et al. 1998). 
In contrast, a striking posterior-anterior nuclear $\beta$-catenin protein gradient is observed in the PSM (Fig. 3C), providing direct evidence for a Wnt/ $\beta$-catenin signaling gradient in mouse embryos (Aulehla et al. 2008). As a result, the Wnt targets Brachyury (Yamaguchi et al. 1999), Mesogenin1 (Wittler et al. 2007), Tbx6 (White et al. 2005), and Axin2 (Jho et al. 2002; Lustig et al. 2002; Aulehla et al. 2003), to mention just a few, all show a posterior-anterior gradient of mRNA expression (Fig. 1).

In summary, graded FGF and Wnt signaling activities are thought to be generated via a distinct decay mechanism and thus can be considered gradients by inheritance. The key requirement for this mode of gradient formation is that cells must leave the zone in which the ligand (either mRNA and/or protein) is exclusively produced-in this case, the tail bud. Once cells undergo this step, ligand concentration can only decrease over time and thus ligand concentration reflects the time since cells left the zone of production. This mode of gradient formation has been formalized in a "cell lineage transport" model and has been shown to occur also at the level of Hoxd13 expression during limb patterning (Ibanes et al. 2006). It is interesting to note that limb proximal-distal development involves the same pathways and apparently similar mechanisms as described in PSM patterning and axis elongation: FGF and Wnt signaling promote distal outgrowth, whereas RA signaling constitutes an opposing, proximal signal (Tabin and Wolpert 2007).

\section{GRADIENT INTERPRETATION AND FUNCTION}

\section{PSM Maturation}

\section{Defining the Determination Front}

As new cells enter the posterior PSM from the tail bud, they become endowed with information specifying their relative position within the PSM. This manifests itself through the peculiar finding that the directionality of somite formation, and thus of differentiation, is already determined even in the most posterior PSM (Menkes and Sandor 1969; Christ et al. 1974; Palmeirim et al. 1998). The differentiation status appears to be controlled by the system of signaling gradients. In this view, high levels of Wnt and FGF signaling maintain cells in an undifferentiated, posterior PSM fate, whereas the exposure to high levels of RA signaling (and concomitant low levels of Wnt and FGF signaling) is responsible for initiating differentiation. An important transition in differentiation status occurs in the anterior one-third of the PSM (Stern et al. 1988; Dubrulle et al. 2001), at a level called the determination front (Dubrulle et al. 2001). Here, it is thought that the somite-forming unit becomes specified (Dubrulle et al. 2001). This developmental switch is accompanied by several important changes on a molecular and morphological level. On a molecular level, once cells pass the determination front, several transcriptional changes occur. First, mesoderm posterior 2 (Mesp2) expression is activated in a somitewide expression domain in response to a periodic signal thought to be provided by the segmentation clock (Saga et al. 1997). Mesp2 is an essential factor in establishing the initial segmental prepattern by defining the future somite boundary position (Saga et al. 1997; Morimoto et al. 2005; Morimoto et al. 2006; Morimoto et al. 2007; Saga 2007). Furthermore, several posterior PSM markers (e.g., Msgn1 and Tbx6) are concomitantly down-regulated in these cells. Another important change concerns the segmentation clock activity, because transcriptional oscillations of the cyclic genes are arrested as cells pass the determination front. Thus, the molecular changes that characterize the determination front level are now known in some detail, allowing analysis of how the gradient systems control this developmental switch.

Morphologically, the posterior PSM is a loose mesenchyme, whereas cells located anterior to the determination front become progressively epithelialized. This transition is accompanied also by a slowing down of PSM cell movements (Delfini et al. 2005). The mesenchymal-epithelial transition occurs 
concomitantly with the segmental patterning of the anterior PSM, correlating with a downregulation of the Snai genes, which in the PSM and tail bud are regulated by FGF signaling (Ciruna and Rossant 2001; Dale et al. 2006). Members of the Snai superfamily have been implicated in the control of epithelialmesenchymal transitions in several different contexts (for review, see Barrallo-Gimeno and Nieto 2005)_for instance, during gastrulation (Carver et al. 2001; Ciruna and Rossant 2001). In the PSM, down-regulation of Snai genes at the determination front level correlates with the expression of several adhesion molecules (e.g., integrins or cadherins), which progressively increase in the anterior PSM as cells become epithelial (Duband et al. 1987; Linask et al. 1998; Horikawa et al. 1999). This transition is also accompanied by the deposition of a basal lamina that surrounds the anterior PSM (Duband et al. 1987; Rifes et al. 2007).

The major spatial control of this developmental switch has been shown to be exerted by the activity of Wnt, FGF, and RA signaling gradients, as supported by functional experiments in fish, Xenopus, chicken, and mouse embryos (Dubrulle et al. 2001; Sawada et al. 2001; Diez del Corral et al. 2003; Moreno and Kintner 2004; Vermot et al. 2005). These studies indicated that a local increase in FGF signaling or a decrease in RA signaling resulted in a delayed or absent differentiation of PSM cells, as judged by the molecular and morphological criteria mentioned above. Likewise, recent genetic evidence supports a central role for the Wnt/ $\beta$-catenin gradient in controlling the differentiation of PSM cells and the positioning of the determination front (Aulehla et al. 2008; Dunty et al. 2008). When the $\beta$-catenin gradient was abolished by introducing a stabilized form of $\beta$-catenin in the PSM of mutant mouse embryos (and thus $\beta$-catenin levels were elevated), the differentiation of PSM was inhibited, paraxial mesoderm cells maintained expression of all markers for posterior PSM identity, and somites did not form (Fig. 3D,E).

Thus, the concept of a gradient system that controls PSM differentiation has received solid experimental support. However, the gradient readout has been investigated only qualitatively, and a quantitative understanding of how this complex gradient system is interpreted on a molecular level is still lacking. In addition, the fact that numerous and complex interactions between the graded signaling systems exist requires that experiments be designed to perturb several pathways simultaneously to gain insight into the epistatic relationship among these multiple signaling pathways in the PSM. In particular, how multiple, graded pathway activities are integrated to result in sharp thresholds (at which a cohort of competent cells undergoes simultaneously a developmental transition) is not understood. Mathematical modeling indicates that the mutual inhibition of FGF and RA signaling can define a bistability domain along the PSM in which such a switch behavior can be observed (Goldbeter et al. 2007) (Fig. 4). Remarkably, a bistable behavior working together with an autonomous clock is systematically observed in in silico simulations of segmentation controlled by a moving gradient as in the clock and wave front model (Francois et al. 2007).

\section{How Does the Gradient Interact with the Segmentation Clock?}

A peculiar characteristic of somite formation is the oscillatory transcriptional activity in PSM cells (reviewed in Dequéant and Pourquié 2008), thought to reflect a molecular clock mechanism that controls the timing of somite formation.

Interestingly, two of the signaling pathways that show a graded activity in the PSM-namely, the Wnt and FGF signaling pathways - have been shown to be involved in this molecular clock and show periodic pulses of activity in the posterior PSM in mouse embryos (Aulehla et al. 2003; Dale et al. 2006; Dequéant et al. 2006; Niwa et al. 2007). The mechanism generating concomitantly graded as well as oscillatory pathway activity is not understood. It is commonly thought that the graded activity of Wnt and FGF signaling is periodically halted via a negative-feedback mechanism. In addition, it appears that 


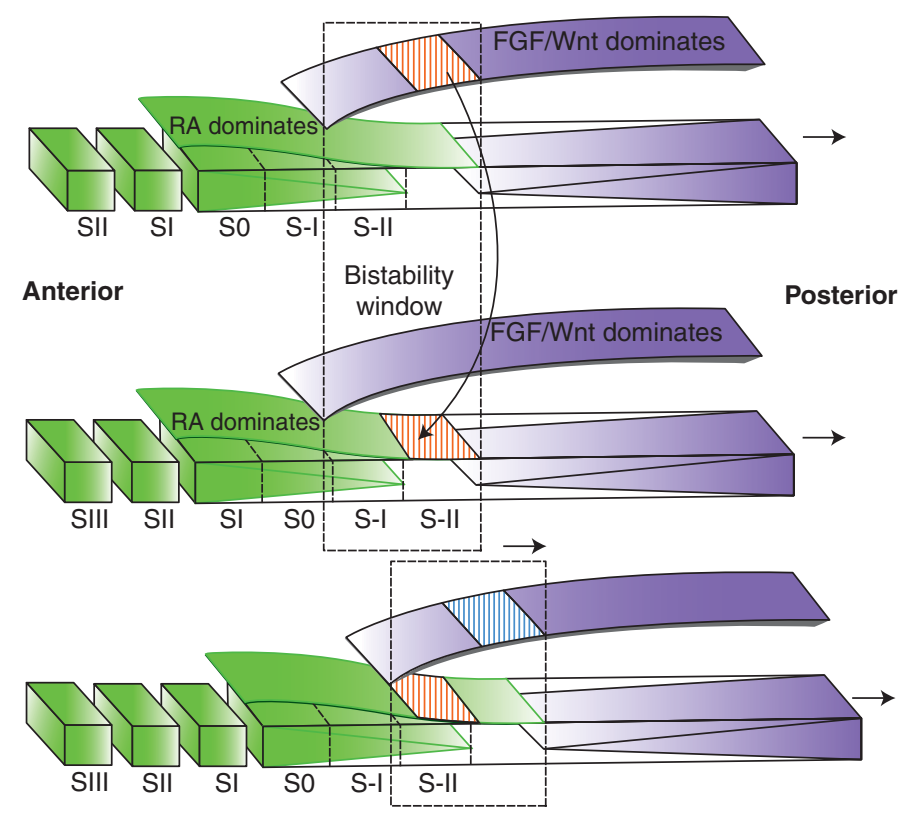

Figure 4. Model for segment determination using opposing gradients to create a bistability domain. Two steady states are proposed to coexist in the PSM. In the posterior part, cells adopt a fibroblast growth factor (FGF)/ Wnt-dominated state (purple), whereas in the anterior PSM the opposing retinoic acid (RA) state dominates (green). Within a window of bistability (dashed rectangle), cells can be triggered to abruptly switch between either of the two steady states. This trigger is proposed to be provided by the periodic signal delivered by the segmentation clock. As a result, a cohort of cells in the bistability domain will be exposed simultaneously to higher levels of RA signaling and, thereby, the segment-forming unit becomes defined (orange). Owing to the posterior extension of the axis and the decay of the FGF and Wnt mRNA and ligands in the PSM, the bistability window constantly moves posteriorly. The next cohort of cells to be simultaneously determined is shown in blue. Note that the bistability window is proposed to be larger than the segment-forming unit, because it comprises also the segment that was defined during the previous cycle and therefore had already responded to the clock signal. In this model, the posterior edge of the bistability window (bifurcation point) corresponds to the determination front.

oscillatory transcription is limited to only a subset of target genes. Again, the underlying mechanism is yet unknown. A third pathway, the Notch signaling pathway, shows periodic signaling activity in all vertebrate species studied, including zebrafish (Holley et al. 2000; Jiang et al. 2000; Sawada et al. 2000; Oates and Ho 2002), Xenopus (Li et al. 2003; Moreno and Kintner 2004), snake (Gomez et al. 2008), lizard (Gomez et al. 2008), and chicken and mouse embryos (reviewed in Dequéant and Pourquié 2008).

The discovery of this molecular clock and of graded FGF and Wnt signaling in the PSM provided the long-awaited experimental support for several theoretical models. Among them, the clock and wave front model and the Meinhardt model postulated the existence of a molecular oscillator in the PSM and a second component-namely a gradient of differentiation that traversed the embryos along the body axis in an anterior-posterior direction (called the morphogen gradient [Meinhardt 1982] or the wave front [Cooke and Zeeman 1976]). In these models, somite formation results from the simultaneous action of this molecular oscillator controlling the timing of somite formation and the action of the gradient system controlling which cells will undergo differentiation. This concept was experimentally supported in several vertebrate species (Dubrulle et al. 2001; Sawada et al. 2001; 
Signaling Gradients

Aulehla et al. 2003; Diez del Corral et al. 2003). These models also predicted that the gradient system would directly (Meinhardt 1982) or indirectly (Cooke and Zeeman 1976) control where the segmentation clock is active. Indeed, experimental evidence indicates that the activity of the molecular clock crucially depends on intact Wnt and FGF signaling in the PSM (Aulehla et al. 2003; Nakaya et al. 2005; Niwa 2007; Wahl et al. 2007). In addition, when the level of $\mathrm{Wnt} / \beta$-catenin signaling in the PSM is experimentally increased in mutant mouse embryos, not only are cells in the PSM prevented from undergoing differentiation, but these cells also show ongoing, ectopic oscillatory activity (Aulehla et al. 2008; Dunty et al. 2008). By using a novel approach based on real-time imaging of segmentation clock activity in mutant mouse embryos, it is possible to directly show that cells continue to undergo segmentation clock oscillations (Aulehla et al. 2008). Together with previous results, these gain-of-function experiments further characterize the relationship between the gradient system and the segmentation clock. In this view, the gradients of Wnt and FGF signaling carry a permissive function that enables oscillations to occur in the posterior PSM, and because of their graded nature, they critically define at which anterior PSM level the segmentation clock activity ceases.

Once cells reach the anterior PSM, the oscillatory activity is translated into a periodic change of cell fate, thus grouping a cohort of cells that will eventually form a somite. Therefore, it is essential to understand how the segmentation clock influences the temporal control of differentiation (e.g., Mesp2 activation). In this respect, much has been learned from the work that has addressed the relationship between Mesp2 activation, the expression of (graded) Tbx6, and the (oscillatory) activity of Notch signaling (Oginuma et al. 2008). Tbx6 controls where Mesp2 is activated and defines its anterior boundary of expression, whereas Mesp2 activation requires additional input from Notch signaling (Takahashi et al. 2000; Moreno and Kintner 2004; Yasuhiko et al. 2006; Oginuma et al. 2008). Because the latter occurs in an oscillatory fashion in the PSM, this could account for the periodic activation of Mesp2. In addition, high levels of FGF (Dubrulle et al. 2001; Delfini et al. 2005) and Wnt signaling (Aulehla et al. 2008; Dunty et al. 2008) repress Mesp2 activation in the posterior PSM. Recent studies, however, indicate that the control of Mesp2 expression, and therefore the definition of the somite-forming unit, is more complex, because constitutive activation of Notch signaling in the PSM of mouse embryos does not disrupt the segmental expression of Mesp2 and subsequent segmentation as one might have expected (Feller et al. 2008).

\section{Gradient Interpretation and Axial Specification}

In addition to the important function of controlling differentiation and defining the somiteforming unit, the gradient system of Wnt, FGF, and RA signaling also appears to be involved in the process that specifies the axial identity of future somites. Although somites appear to be similar at the time of formation along the body axis, they subsequently will develop into very distinct structures depending on their axial position-cervical, thoracic, lumbar, and sacral vertebrae have distinct morphological features and unique functions. Interestingly, classical experimental embryology studies indicate that the determination of axial identity takes place in mesodermal cells before these cells are actually incorporated into a somite (Kieny et al. 1972; Jacob et al. 1975). Thus, the heterotopic transplantation of unsegmented paraxial mesoderm from the prospective thoracic region into the cervical or lumbosacral region of a host embryo results in the formation of ectopic ribs (Kieny et al. 1972; Jacob et al. 1975). Molecularly, the determination of the axial identity has been shown to be tightly linked to the action of Hox genes (Kmita and Duboule 2003; Wellik 2007), which encode homeobox-containing transcription factors (Graham et al. 1989; Krumlauf 1994). As mentioned above, axial identity of vertebrae seems to be determined while cells reside in the 
PSM. Accordingly, it has been shown that modulation of Hox gene expression in the PSM can drastically alter the resulting axial identity of future vertebrae (Carapuco et al. 2005).

What is the connection between axial identity, Hox genes, and the system of graded RA, Wnt, and FGF signaling? It is important to first distinguish between the initiation of Hox gene expression during gastrulation and the subsequent repositioning of expression boundaries within the PSM and somites (Deschamps and van Nes 2005). During the initiation phase, Hox genes become activated in a striking temporal collinearity within the primitive streak region. This precise sequential activation serves a critical function in contributing to the final spatial collinearity along the body axis (Forlani et al. 2003; Juan and Ruddle 2003; Wacker et al. 2004; Iimura and Pourquié 2006), which ultimately determines axial identity. Importantly, however, this initial blueprint does not entirely match the definitive Hox gene expression (Forlani et al. 2003). Thus, the definitive Hox gene identity does not strictly result from the collinear initiation phase alone, but also from extensive modification of Hox gene expression occurring after cells exit the primitive streak and before they are incorporated into a somite (i.e., while located in the PSM).

\section{PSM Gradients, Segmentation Clock, and Hox Gene Expression}

It is during the phase of Hox gene expression in PSM cells that a first connection between the system of graded signaling activity and Hox genes was discovered: A local perturbation of the Fgf8 gradient led to the formation of smaller somites and this phenotype was accompanied by a change in Hox gene expression (Dubrulle et al. 2001). Thus, cells expressed Hox genes that matched the respective somite number to which they were allocated, although this somite was located at a slightly more anterior axial position than in control embryos. In other words, Hox gene expression matched respective somite numbers, not the absolute axial position (Dubrulle et al. 2001). Additional evidence indicates that Notch signaling, which shows oscillating activity in the PSM across several vertebrate species (Dequéant and Pourquié 2008), also is involved in controlling Hox gene expression in the PSM (Zakany et al. 2001; Cordes et al. 2004). Because, in turn, these oscillations of Notch signaling are critically dependent on Wnt (Aulehla et al. 2003; Nakaya et al. 2005; Satoh et al. 2006; Aulehla et al. 2008; Dunty et al. 2008) and FGF signaling gradients (Niwa et al. 2007; Wahl et al. 2007), these findings suggest that the acquisition of a definitive Hox gene expression is connected to the system of PSM gradients.

\section{Homeotic Transformations Linked to $R A$, Wnt, and FGF Signaling}

A different set of arguments is based on the findings that the perturbation of RA, Wnt, and FGF signaling causes a change in vertebral axial identity (homeotic transformations) and in Hox gene expression in mouse embryos. For instance, increasing RA signaling levels in developing mouse embryos causes homeotic transformations that, depending on the time of treatment, cause vertebrae to acquire either more anterior or more posterior identities (Kessel and Gruss 1991). This important function of RA signaling in specifying vertebral axial identity and the control of Hox genes was later confirmed through genetic deletion of RA signaling components (Lohnes et al. 1994). Likewise, functional experiments targeting FGF signaling resulted in homeotic transformations and a change in Hox gene expression, again linking axial specification and the gradient of FGF signaling (Partanen et al. 1998). Finally, Wnt signaling has also been connected directly to the process of axial specification. In Wnt3a mutant embryos (Ikeya and Takada 2001) or in Wnt3a hypomorphic embryos vestigial tail $(v t)$, homeotic transformations and corresponding changes in Hox gene expression are likewise observed (Greco et al. 1996). These functional studies emphasize the importance of Wnt, FGF, and 
Signaling Gradients

RA signaling in the process of axial specification and control of Hox genes. However, it remains unclear whether this function is exerted at the level of Hox gene initiation during primitive streak formation or Hox gene repositioning in the PSM (or both). This is complicated because Wnt and FGF signaling carry essential functions both during primitive streak formation/gastrulation, as well as during the segmentation process within the PSM. Nevertheless, an interesting molecular link between RA, Wnt, and FGF signaling and Hox gene expression (and thus axial identity) exists at the level of caudal-like homeobox genes (Cdx). $C d x 1,-2$, and -4 can directly activate Hox gene expression (reviewed in Lohnes 2003) and are targets of Wnt (Lickert et al. 2000; Ikeya and Takada 2001; Prinos et al. 2001; Lickert and Kemler 2002; Pilon et al. 2006), FGF (in Xenopus, Pownall et al. 1996; Keenan et al. 2006), and RA signaling (Houle et al. 2000; Lickert and Kemler 2002). Functionally, Cdx gene products have been shown to control anteroposterior (AP) axis development through their actions on Hox genes (van den Akker et al. 2002; Chawengsaksophak et al. 2004; van Nes et al. 2006). Furthermore, the role of the caudal and caudal-related genes appears to be largely evolutionarily conserved (Copf et al. 2004); thus potentially suggesting a key role in patterning the AP axis of Bilateria.

\section{Control of Gastrulation Movements by Wnt and FGF Signaling-The Case of Temporal Gradients?}

In respect to their function during gastrulation and axis development, it has been suggested that Wnt and FGF signaling are required in a dosedependent manner. In allelic series experiments in mouse embryos mutant for Wnt3a (Greco et al. 1996), Brachyury (T) (Stott et al. 1993), and Fgfr1 (Partanen et al. 1998), axis truncation occurred at more anterior levels as gene activity was progressively decreased. Elegant chimera experiments involving both gain- and loss-of-function experiments provide clear support for a dose-dependent function of Brachyury (Wilson et al. 1995; Wilson and
Beddington 1997), a target of Wnt3a (Yamaguchi et al. 1999; Arnold et al. 2000), in controlling morphogenetic gastrulation movements (e.g., cell exit from the primitive streak). A similar defect in morphogenetic cell movement in mesoderm progenitor cells has been described in Fgfrl mutants (Ciruna et al. 1997).

Interesting recent findings in chicken embryos indicate that these morphogenetic movements of mesoderm progenitors are controlled by the temporal sequence of Hox gene expression (Iimura and Pourquié 2006). Thus, because both the Wnt3a target Brachyury and the FGF signaling on one side and Hox genes on the other side are implicated in the control of continuing gastrulation movements during axis elongation, the possibility has been raised that even during the early initiation phase of Hox gene expression, a tight interaction may exist. Although the causal relationship between these observations remains to be firmly established, we discuss two, nonexclusive mechanisms of how this interaction might occur (Fig. 5).

In the first scenario (gradient-over-time), the level of Wnt and FGF signaling activity increases during the course of development in paraxial progenitors located in the primitive streak and tail bud. This increase would be essential to ensure ongoing gastrulation movements and hence to replenish the paraxial mesoderm. Furthermore, this function could be exerted via sequential activation of Hox genes. In this view, Wnt and FGF signaling would act in a dose-dependent manner on the activation of Hox genes in paraxial progenitors. Indeed, overactivation of FGF signaling has been shown to lead to ectopic activation of 5' Hox genes during Xenopus gastrulation (Pownall et al. 1996) and, conversely, FGF signaling is required for the initiation of Hox gene expression (Pownall et al. 1998). The gradient-over-time model, therefore, could explain the findings that functional perturbation of Wnt and FGF signaling leads to axis truncation in a dose-dependent manner (via its function on morphogenetic movements of paraxial progenitors) and, concomitantly, 
A. Aulehla and O. Pourquié

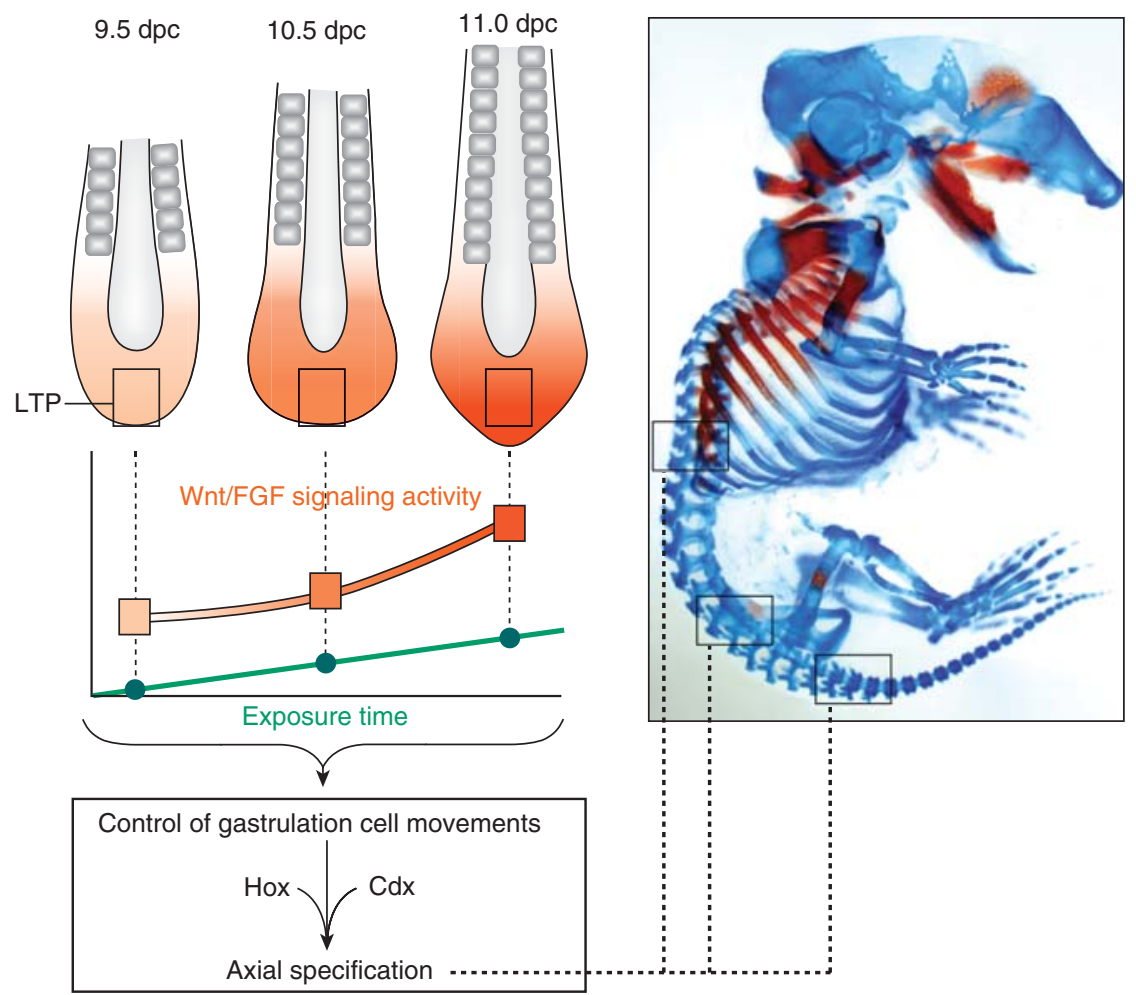

Figure 5. Model of temporal gradients in paraxial mesoderm precursors. The posterior region of three mouse embryos at day $9.5 \mathrm{dpc}, 10.5 \mathrm{dpc}$, and $11.0 \mathrm{dpc}$ are shown schematically and the zone of paraxial progenitors (long-term progenitors [LTP]) is highlighted (black box). Within this LTP, Wnt and FGF signaling might increase over time (plotted in orange), for instance, because of progressive accumulation of the ligands. Also, the exposure time of LTP to Wnt and FGF signals might increase over time (plotted in green). In this model, these gradients are proposed to control cell movements during gastrulation (e.g., the timing of how cells exit the primitive streak) and hence control replenishment of the PSM. Together with Hox genes and possibly via $\mathrm{Cdx}$ genes, these potential gradients could contribute to axial specification of vertebrae identity. This results in vertebrae with unique features along the AP axis, as shown in a mouse embryo at day $14.5 \mathrm{dpc}$.

leads to homeotic transformations (via its action on Hox genes). A challenge to this model could be the expectation that an increase in Wnt and FGF signaling in mesodermal progenitors would also result in a change of the PSM gradient (e.g., a change in the position of the determination front) during the course of development. In fact, although the determination front position within the PSM is kept relatively constant during the course of development (Gomez et al. 2008), its AP position does change dramatically in absolute terms, and PSM gradients and size change continuously as well (Tam 1981). Thus, additional factors, such as mRNA and protein turnover rates in the PSM, must be taken into account and can explain that the relative position of the determination front remains constant, although the starting value in the posterior embryo might increase.

The second mechanism (gradient-in-time) takes into account the finding of a pool of long-term progenitors that contribute descendants to the entire body axis. These longterm progenitors have been identified in the primitive streak and tail bud (Nicolas et al. 
1996; Eloy-Trinquet et al. 2000; Cambray and Wilson 2002; Eloy-Trinquet and Nicolas 2002a; Eloy-Trinquet and Nicolas 2002b; Iimura and Pourquié 2006; Cambray and Wilson 2007; McGrew et al. 2008). Based on these findings, one can assume that these progenitors will naturally be exposed for an increasing amount of time to signals of the Wnt and FGF pathways while residing in the primitive streak and the tail bud. In this view, the increase in exposure time rather than an increase in dosage would specify a more posterior fate. It has been proposed that such a mechanism functions during limb AP patterning (Yang et al. 1997; Harfe et al. 2004; Dessaud et al. 2007; Scherz et al. 2007), in which digits 3 to 5 are specified according to the time cells are exposed to sonic hedgehog (shh) signaling. In contrast to these limb patterning studies, no experimental evidence is currently available supporting a gradient-in-time mechanism during axial specification and, therefore, this remains to be tested.

\section{CONCLUSION}

Similar to the situation in the anterior PSM and the control of PSM differentiation, a quantitative understanding of how RA, Wnt, and FGF signaling in the primitive streak and the tail bud affects the control of vertebral axial identity is still lacking and represents an exciting future goal. Specifically, it will be important to obtain a comprehensive view of how PSM gradients, temporal gradients in the tail bud, and the segmentation clock interact to control these various aspects of embryonic development. Part of this challenge is the high degree of interaction and mutual regulation of all involved signaling machineries, which, in addition, is highly context-dependent. For instance, although an antagonistic relationship between RA signaling and FGF/Wnt signaling appears to exist during PSM differentiation, all three pathways are considered to have a posteriorizing effect on axial development and thus appear to work synergistically in this context (reviewed in Stern et al. 2006). The complexity and dynamic nature of these phenomena is also underscored by the findings that, for instance, activation of RA signaling can cause both anterior and posterior homeotic transformations, depending on the time point of activation (Kessel and Gruss 1991; Kessel 1992). Finally, it has also been suggested that the tight interaction of multiple gradients (e.g., the antagonism between RA and FGF signaling) underlies the termination of axial elongation (Gomez et al. 2008).

Resolving the complex and apparently dynamic network associated with gradient formation and interpretation during the process of somite formation and axis development offers the exciting opportunity to gain a more general insight into the mechanisms underlying the head-to-tail progression, or timing, of embryonic development.

\section{ACKNOWLEDGMENTS}

The authors thank members of the Pourquié lab for comments, S. Esteban for artwork, and J. Chatfield for manuscript editing. A.A. was funded by the Swiss Foundation for MedicalBiological Grants/Swiss National Science Foundation. This research was supported by Stowers Institute for Medical Research. O.P. is a Howard Hughes Medical Institute Investigator.

\section{REFERENCES}

Arnold SJ, Stappert J, Bauer A, Kispert A, Herrmann BG Kemler R. 2000. Brachyury is a target gene of the Wnt/ $\beta$-catenin signaling pathway. Mech Dev 91: 249-258.

Aulehla A, Herrmann BG. 2004. Segmentation in vertebrates: Clock and gradient finally joined. Genes Dev 18: 2060-2067.

Aulehla A, Wehrle C, Brand-Saberi B, Kemler R, Gossler A, Kanzler B, Herrmann BG. 2003. Wnt3a plays a major role in the segmentation clock controlling somitogenesis. Dev Cell 4: 395-406.

Aulehla A, Wiegraebe W, Baubet V, Wahl MB, Deng C, Taketo M, Lewandoski M, Pourquié O. 2008. A $\beta$-catenin gradient links the clock and wavefront systems in mouse embryo segmentation. Nat Cell Biol 10: $186-193$.

Barrallo-Gimeno A, Nieto MA. 2005. The Snail genes as inducers of cell movement and survival: Implications in development and cancer. Development 132: 3151-3161.

Bottcher RT, Niehrs C. 2005. Fibroblast growth factor signaling during early vertebrate development. Endocr Rev 26: 63-77. 
Bronner-Fraser M. 1986. Analysis of the early stages of trunk neural crest migration in avian embryos using monoclonal antibody HNK-1. Dev Biol 115: 44-55.

Cambray N, Wilson V. 2002. Axial progenitors with extensive potency are localised to the mouse chordoneural hinge. Development 129: 4855-4866.

Cambray N, Wilson V. 2007. Two distinct sources for a population of maturing axial progenitors. Development 134: $2829-2840$

Carapuco M, Nóvoa A, Bobola N, Mallo M. 2005. Hox genes specify vertebral types in the presomitic mesoderm. Genes Dev 19: 2116-2121.

Carver EA, Jiang R, Lan Y, Oram KF, Gridley T. 2001. The mouse snail gene encodes a key regulator of the epithelialmesenchymal transition. Mol Cell Biol 21: 8184-8188.

Chawengsaksophak K, de Graaff W, Rossant J, Deschamps J, Beck F. 2004. $C d x 2$ is essential for axial elongation in mouse development. Proc Natl Acad Sci 101: 7641-7645.

Christ B, Ordahl CP. 1995. Early stages of chick somite development. Anat Embryol 191: 381-396.

Christ B, Jacob HJ, Jacob M. 1974. Somitogenesis in the chick embryo. Determination of the segmentation direction. Verh Anat Ges 68: 573-579.

Ciruna B, Rossant J. 2001. FGF signaling regulates mesoderm cell fate specification and morphogenetic movement at the primitive streak. Dev Cell 1: 37-49.

Ciruna BG, Schwartz L, Harpal K, Yamaguchi TP, Rossant J. 1997. Chimeric analysis of fibroblast growth factor receptor-1 (Fgfr1) function: A role for FGFR1 in morphogenetic movement through the primitive streak. Development 124: 2829-2841.

Cooke J, Zeeman EC. 1976. A clock and wavefront model for control of the number of repeated structures during animal morphogenesis. J Theor Biol 58: 455-476.

Copf T, Schroder R, Averof M. 2004. Ancestral role of caudal genes in axis elongation and segmentation. Proc Natl Acad Sci 101: 17711-17715.

Cordes R, Schuster-Gossler K, Serth K, Gossler A. 2004 Specification of vertebral identity is coupled to Notch signalling and the segmentation clock. Development 131: $1221-1233$.

Dale JK, Malapert P, Chal J, Vilhais-Neto G, Maroto M, Johnson T, Jayasinghe S, Trainor P, Herrmann B, Pourquié O. 2006. Oscillations of the snail genes in the presomitic mesoderm coordinate segmental patterning and morphogenesis in vertebrate somitogenesis. Dev Cell 10: 355-366.

Delfini MC, Dubrulle J, Malapert P, Chal J, Pourquié O. 2005. Control of the segmentation process by graded MAPK/ERK activation in the chick embryo. Proc Nat Acad Sci 102: 11343-11348.

Dequéant ML, Glynn E, Gaudenz K, Wahl M, Chen J, Mushegian A, Pourquié O. 2006. A complex oscillating network of signaling genes underlies the mouse segmentation clock. Science 314: 1595-1598.

Dequéant ML, Pourquié O. 2008. Segmental patterning of the vertebrate embryonic axis. Nat Rev Genet 9: 370-382.

Deschamps J, van Nes J. 2005. Developmental regulation of the Hox genes during axial morphogenesis in the mouse. Development 132: 2931-2942.
Dessaud E, Yang LL, Hill K, Cox B, Ulloa F, Ribeiro A, Mynett A, Novitch BG, Briscoe J. 2007. Interpretation of the sonic hedgehog morphogen gradient by a temporal adaptation mechanism. Nature 450: 717-720.

Diez del Corral R, Olivera-Martinez I, Goriely A, Gale E, Maden M, Storey K. 2003. Opposing FGF and retinoid pathways control ventral neural pattern, neuronal differentiation, and segmentation during body axis extension. Neuron 40: 65-79.

Duband JL, Dufour S, Hatta K, Takeichi M, Edelman GM, Thiery JP. 1987. Adhesion molecules during somitogenesis in the avian embryo. J Cell Biol 104: 1361-1374.

Dubrulle J, Pourquié O. 2004a. Coupling segmentation to axis formation. Development 131: 5783-5793.

Dubrulle J, Pourquié O. 2004b. $f g f 8$ mRNA decay establishes a gradient that couples axial elongation to patterning in the vertebrate embryo. Nature 427: 419-422.

Dubrulle J, McGrew MJ, Pourquié O. 2001. FGF signaling controls somite boundary position and regulates segmentation clock control of spatiotemporal Hox gene activation. Cell 106: 219-232.

Dunty WC Jr, Biris KK, Chalamalasetty RB, Taketo MM, Lewandoski M, Yamaguchi TP. 2008. Wnt3a/ $\beta$-catenin signaling controls posterior body development by coordinating mesoderm formation and segmentation. Development 135: 85-94.

Eichele G, Thaller C. 1987. Characterization of concentration gradients of a morphogenetically active retinoid in the chick limb bud. J Cell Biol 105: 1917-1923.

Eloy-Trinquet S, Nicolas JF. 2002a. Cell coherence during production of the presomitic mesoderm and somitogenesis in the mouse embryo. Development 129: 3609-3619.

Eloy-Trinquet S, Nicolas JF. 2002b. Clonal separation and regionalisation during formation of the medial and lateral myotomes in the mouse embryo. Development 129: $111-122$.

Eloy-Trinquet S, Mathis L, Nicolas JF. 2000. Retrospective tracing of the developmental lineage of the mouse myotome. Curr Top Dev Biol 47: 33-80.

Feller J, Schneider A, Schuster-Gossler K, Gossler A. 2008. Noncyclic Notch activity in the presomitic mesoderm demonstrates uncoupling of somite compartmentalization and boundary formation. Genes Dev 22: 2166-2171.

Forlani S, Lawson KA, Deschamps J. 2003. Acquisition of Hox codes during gastrulation and axial elongation in the mouse embryo. Development 130: 3807-3819.

Francois P, Hakim V, Siggia ED. 2007. Deriving structure from evolution: Metazoan segmentation. Mol Syst Biol 3: 154 .

Fujii H, Sato T, Kaneko S, Gotoh O, Fujii-Kuriyama Y, Osawa K, Kato S, Hamada H. 1997. Metabolic inactivation of retinoic acid by a novel P450 differentially expressed in developing mouse embryos. EMBO J 16: 4163-4173.

Goldbeter A, Gonze D, Pourquié O. 2007. Sharp developmental thresholds defined through bistability by antagonistic gradients of retinoic acid and FGF signaling. Dev Dyn 236: 1495-1508.

Gomez C, Ozbudak EM, Wunderlich J, Baumann D, Lewis J, Pourquié O. 2008. Control of segment number in vertebrate embryos. Nature 454: 335-339. 
Graham A, Papalopulu N, Krumlauf R. 1989. The murine and Drosophila homeobox gene complexes have common features of organization and expression. Cell 57: $367-378$.

Greco TL, Takada S, Newhouse MM, McMahon JA, McMahon AP, Camper SA. 1996. Analysis of the vestigial tail mutation demonstrates that Wnt-3a gene dosage regulates mouse axial development. Genes Dev 10: 313-324.

Gurdon JB, Bourillot PY. 2001. Morphogen gradient interpretation. Nature 413: 797-803.

Harfe BD, Scherz PJ, Nissim S, Tian H, McMahon AP, Tabin CJ. 2004. Evidence for an expansion-based temporal Shh gradient in specifying vertebrate digit identities. Cell 118: 517-528.

Holley SA, Geisler R, Nüsslein-Volhard C. 2000. Control of herl expression during zebrafish somitogenesis by a Delta-dependent oscillator and an independent wavefront activity. Genes Dev 14: 1678-1690.

Horikawa K, Radice G, Takeichi M, Chisaka O. 1999. Adhesive subdivisions intrinsic to the epithelial somites. Dev Biol 215: 182-189.

Houle M, Prinos P, Iulianella A, Bouchard N, Lohnes D. 2000. Retinoic acid regulation of Cdxl: An indirect mechanism for retinoids and vertebral specification. Mol Cell Biol 20: 6579-6586.

Ibanes M, Kawakami Y, Rasskin-Gutman D, Belmonte JC. 2006. Cell lineage transport: A mechanism for molecular gradient formation. Mol Syst Biol 2: 57.

Iimura T, Pourquié O. 2006. Collinear activation of Hoxb genes during gastrulation is linked to mesoderm cell ingression. Nature 442: 568-571.

Ikeya M, Takada S. 2001. Wnt-3a is required for somite specification along the anteroposterior axis of the mouse embryo and for regulation of $c d x-1$ expression. Mech Dev 103: $27-33$.

Jacob M, Christ B, Jacob HJ. 1975. Regional determination of the paraxial mesoderm in young chick embryos. Verh Anat Ges 69: 263-269.

Jho EH, Zhang $\mathrm{T}$, Domon C, Joo CK, Freund JN, Costantini F. 2002. Wnt/ $\beta$-catenin/Tcf signaling induces the transcription of Axin2, a negative regulator of the signaling pathway. Mol Cell Biol 22: 1172-1183.

Jiang YJ, Aerne BL, Smithers L, Haddon C, Ish-Horowicz D, Lewis J. 2000. Notch signalling and the synchronization of the somite segmentation clock. Nature 408: 475-479.

Juan AH, Ruddle FH. 2003. Enhancer timing of Hox gene expression: Deletion of the endogenous Hoxc8 early enhancer. Development 130: 4823-4834.

Keenan ID, Sharrard RM, Isaacs HV. 2006. FGF signal transduction and the regulation of Cdx gene expression. Dev Biol 299: 478-488.

Kessel M. 1992. Respecification of vertebral identities by retinoic acid. Development 115: 487-501.

Kessel M, Gruss P. 1991. Homeotic transformations of murine vertebrae and concomitant alteration of Hox codes induced by retinoic acid. Cell 67: 89-104.

Keynes RJ, Stern CD. 1984. Segmentation in the vertebrate nervous system. Nature 310: 786-789.
Kieny M, Mauger A, Sengel P. 1972. Early regionalization of somitic mesoderm as studied by the development of axial skeleton of the chick embryo. Dev Biol 28: 142-161.

Kmita M, Duboule D. 2003. Organizing axes in time and space; 25 years of colinear tinkering. Science 301: $331-333$.

Krumlauf R. 1994. Hox genes in vertebrate development. Cell 78: 191-201.

Li Y, Fenger U, Niehrs C, Pollet N. 2003. Cyclic expression of esr9 gene in Xenopus presomitic mesoderm. Differentiation 71: 83-89.

Li C, Scott DA, Hatch E, Tian X, Mansour SL. 2007. Dusp6 $(M k p 3)$ is a negative feedback regulator of FGFstimulated ERK signaling during mouse development. Development 134: 167-176.

Lickert H, Kemler R. 2002. Functional analysis of cisregulatory elements controlling initiation and maintenance of early $C d x 1$ gene expression in the mouse. Dev Dyn 225: 216-220.

Lickert H, Domon C, Huls G, Wehrle C, Duluc I, Clevers H, Meyer BI, Freund JN, Kemler R. 2000. Wnt/ $\beta$-catenin signaling regulates the expression of the homeobox gene $C d x 1$ in embryonic intestine. Development 127: 3805-3813.

Linask KK, Ludwig C, Han MD, Liu X, Radice GL, Knudsen KA. 1998. N-cadherin/catenin-mediated morphoregulation of somite formation. Dev Biol 202: 85-102.

Lohnes D. 2003. The Cdx1 homeodomain protein: An integrator of posterior signaling in the mouse. Bioessays 25: 971-980.

Lohnes D, Mark M, Mendelsohn C, Dolle P, Dierich A, Gorry P, Gansmuller A, Chambon P. 1994. Function of the retinoic acid receptors (RARs) during development. I Craniofacial and skeletal abnormalities in RAR double mutants. Development 120: 2723-2748.

Lustig B, Jerchow B, Sachs M, Weiler S, Pietsch T, Karsten U, van de Wetering $\mathrm{M}$, Clevers $\mathrm{H}$, Schlag PM, Birchmeier W, et al. 2002. Negative feedback loop of Wnt signaling through upregulation of conductin/axin2 in colorectal and liver tumors. Mol Cell Biol 22: 1184-1193.

McGrew MJ, Sherman A, Lillico SG, Ellard FM, Radcliffe PA, Gilhooley HJ, Mitrophanous KA, Cambray N, Wilson V, Sang H. 2008. Localised axial progenitor cell populations in the avian tail bud are not committed to a posterior Hox identity. Development 135: 2289-2299.

Meinhardt H. 1982. Models of biological pattern formation. Academic Press, London.

Menkes B, Sandor S. 1969. Researches on the development of axial organs. V. Rev Roum Embryol 6: 65-72.

Moreno TA, Kintner C. 2004. Regulation of segmental patterning by retinoic acid signaling during Xenopus somitogenesis. Dev Cell 6: 205-218.

Morimoto M, Takahashi Y, Endo M, Saga Y. 2005. The Mesp2 transcription factor establishes segmental borders by suppressing Notch activity. Nature 435: 354-359.

Morimoto M, Kiso M, Sasaki N, Saga Y. 2006. Cooperative Mesp activity is required for normal somitogenesis along the anterior-posterior axis. Dev Biol 300: 687-698.

Morimoto M, Sasaki N, Oginuma M, Kiso M, Igarashi K, Aizaki K, Kanno J, Saga Y. 2007. The negative regulation 
of Mesp2 by mouse Ripply2 is required to establish the rostro-caudal patterning within a somite. Development 134: $1561-1569$.

Nakaya MA, Biris K, Tsukiyama T, Jaime S, Rawls JA, Yamaguchi TP. 2005. Wnt3a links left-right determination with segmentation and anteroposterior axis elongation. Development 132: 5425-5436.

Nicolas JF, Mathis L, Bonnerot C, Saurin W. 1996. Evidence in the mouse for self-renewing stem cells in the formation of a segmented longitudinal structure, the myotome. Development 122: 2933-2946.

Niederreither K, Dolle P. 2008. Retinoic acid in development: Towards an integrated view. Nat Rev Genet 9: 541-553.

Niederreither K, McCaffery P, Drager UC, Chambon P, Dolle P. 1997. Restricted expression and retinoic acidinduced downregulation of the retinaldehyde dehydrogenase type 2 (RALDH-2) gene during mouse development. Mech Dev 62: 67-78.

Niwa H. 2007. How is pluripotency determined and maintained? Development 134: 635-646.

Niwa Y, Masamizu Y, Liu T, Nakayama R, Deng CX, Kageyama R. 2007. The initiation and propagation of Hes7 oscillation are cooperatively regulated by Fgf and Notch signaling in the somite segmentation clock. Dev Cell 13: 298-304.

Nusse R. 2005. Wnt signaling in disease and in development. Cell Res 15: 28-32.

Oates AC, Ho RK. 2002. Hairy/E(spl)-related (Her) genes are central components of the segmentation oscillator and display redundancy with the Delta/Notch signaling pathway in the formation of anterior segmental boundaries in the zebrafish. Development 129: 2929-2946.

Oginuma M, Niwa Y, Chapman DL, Saga Y. 2008. Mesp2 and Tbx6 cooperatively create periodic patterns coupled with the clock machinery during mouse somitogenesis. Development 135: 2555-2562.

Packard DSJ, Jacobson A. 1976. The influence of axial structures on chick somite formation. Dev Biol 53: 36-48.

Palmeirim I, Henrique D, Ish-Horowicz D, Pourquié O. 1997. Avian hairy gene expression identifies a molecular clock linked to vertebrate segmentation and somitogenesis. Cell 91: 639-648.

Palmeirim I, Dubrulle J, Henrique D, Ish-Horowicz D, Pourquié O. 1998. Uncoupling segmentation and somitogenesis in the chick presomitic mesoderm. Dev Genet 23: 77-85.

Partanen J, Schwartz L, Rossant J. 1998. Opposite phenotypes of hypomorphic and Y766 phosphorylation site mutations reveal a function for $F g f r l$ in anteroposterior patterning of mouse embryos. Genes Dev 12: 2332-2344.

Pilon N, Oh K, Sylvestre JR, Bouchard N, Savory J, Lohnes D. 2006. $C d x 4$ is a direct target of the canonical Wnt pathway. Dev Biol 289: 55-63.

Pownall ME, Tucker AS, Slack JM, Isaacs HV. 1996. eFGF $X c a d 3$ and Hox genes form a molecular pathway that establishes the anteroposterior axis in Xenopus. Development 122: 3881-3892.

Pownall ME, Isaacs HV, Slack JM. 1998. Two phases of Hox gene regulation during early Xenopus development. Curr Biol 8: 673-676.
Prinos P, Joseph S, Oh K, Meyer BI, Gruss P, Lohnes D. 2001. Multiple pathways governing $C d x 1$ expression during murine development. Dev Biol 239: 257-269.

Rickmann M, Fawcett JW, Keynes RJ. 1985. The migration of neural crest cells and the growth of motor axons through the rostral half of the chick somite. J Embryol Exp Morphol 90: 437-455.

Rifes P, Carvalho L, Lopes C, Andrade RP, Rodrigues G, Palmeirim I, Thorsteinsdottir S. 2007. Redefining the role of ectoderm in somitogenesis: A player in the formation of the fibronectin matrix of presomitic mesoderm. Development 134: 3155-3165.

Roehl H, Nüsslein-Volhard C. 2001. Zebrafish pea3 and erm are general targets of FGF8 signaling. Curr Biol 11: 503-507.

Rossant J, Zirngibl R, Cado D, Shago M, Giguère V. 1991. Expression of a retinoic acid response element-hsplacZ transgene defines specific domains of transcriptional activity during mouse embryogenesis. Genes Dev 5: 1333-1344.

Saga Y. 2007. Segmental border is defined by the key transcription factor Mesp2, by means of the suppression of Notch activity. Dev Dyn 236: 1450-1455.

Saga Y, Hata N, Koseki H, Taketo MM. 1997. Mesp2: A novel mouse gene expressed in the presegmented mesoderm and essential for segmentation initiation. Genes Dev 11: 1827-1839.

Sakai Y, Meno C, Fujii H, Nishino J, Shiratori H, Saijoh Y, Rossant J, Hamada H. 2001. The retinoic acidinactivating enzyme CYP26 is essential for establishing an uneven distribution of retinoic acid along the anterioposterior axis within the mouse embryo. Genes Dev 15: 213-225.

Satoh W, Gotoh T, Tsunematsu Y, Aizawa S, Shimono A. 2006. Sfrp1 and Sfrp2 regulate anteroposterior axis elongation and somite segmentation during mouse embryogenesis. Development 133: 989-999.

Sawada A, Fritz A, Jiang Y, Yamamoto A, Yamasu K, Kuroiwa A, Saga Y, Takeda H. 2000. Zebrafish Mesp family genes, mesp- $a$ and mesp- $b$ are segmentally expressed in the presomitic mesoderm, and Mesp-b confers the anterior identity to the developing somites. Development 127: 1691-1702.

Sawada A, Shinya M, Jiang YJ, Kawakami A, Kuroiwa A, Takeda H. 2001. Fgf/MAPK signalling is a crucial positional cue in somite boundary formation. Development 128: $4873-4880$.

Scherz PJ, McGlinn E, Nissim S, Tabin CJ. 2007. Extended exposure to Sonic hedgehog is required for patterning the posterior digits of the vertebrate limb. Dev Biol 308: 343-354.

Seidensticker MJ, Behrens J. 2000. Biochemical interactions in the wnt pathway. Biochim Biophys Acta 1495: 168-182.

Stern CD, Fraser SE, Keynes RJ, Primmett DR. 1988. A cell lineage analysis of segmentation in the chick embryo. Development 104: 231-244.

Stern CD, Charite J, Deschamps J, Duboule D, Durston AJ, Kmita M, Nicolas JF, Palmeirim I, Smith JC, Wolpert L. 2006. Head-tail patterning of the vertebrate embryo: One, two or many unresolved problems? Int J Dev Biol 50: $3-15$. 
Stott D, Kispert A, Herrmann BG. 1993. Rescue of the tail defect of Brachyury mice. Genes Dev 7: 197-203.

Tabin C, Wolpert L. 2007. Rethinking the proximodistal axis of the vertebrate limb in the molecular era. Genes Dev 21: 1433-1442.

Takada S, Stark KL, Shea MJ, Vassileva G, McMahon JA, McMahon AP. 1994. Wnt-3a regulates somite and tailbud formation in the mouse embryo. Genes Dev 8: 174-189.

Takahashi Y, Koizumi K, Takagi A, Kitajima S, Inoue T, Koseki H, Saga Y. 2000. Mesp2 initiates somite segmentation through the Notch signalling pathway. Nat Genet 25: 390-396.

Tam PP. 1981. The control of somitogenesis in mouse embryos. J Embryol Exp Morphol (suppl.) 65: 103-128.

Teillet MA, Kalcheim C, Le Douarin NM. 1987. Formation of the dorsal root ganglia in the avian embryo: Segmental origin and migratory behavior of neural crest progenitor cells. Dev Biol 120: 329-347.

van den Akker E, Forlani S, Chawengsaksophak K, de Graaff W, Beck F, Meyer BI, Deschamps J. 2002. CdxI and $C d x 2$ have overlapping functions in anteroposterior patterning and posterior axis elongation. Development 129: $2181-2193$.

van Nes J, de Graaff W, Lebrin F, Gerhard M, Beck F, Deschamps J. 2006. The $C d x 4$ mutation affects axial development and reveals an essential role of Cdx genes in the ontogenesis of the placental labyrinth in mice. Development 133: 419-428.

Vermot J, Pourquié O. 2005. Retinoic acid coordinates somitogenesis and left-right patterning in vertebrate embryos. Nature 435: 215-220.

Vermot J, Llamas JG, Fraulob V, Niederreither K, Chambon P, Dolle P. 2005. Retinoic acid controls the bilateral symmetry of somite formation in the mouse embryo. Science 308: 563-566.

Wacker SA, Jansen HJ, McNulty CL, Houtzager E, Durston AJ. 2004. Timed interactions between the Hox expressing non-organiser mesoderm and the Spemann organiser generate positional information during vertebrate gastrulation. Dev Biol 268: 207-219.
Wahl MB, Deng C, Lewandoski M, Pourquié O. 2007. FGF signaling acts upstream of the NOTCH and WNT signaling pathways to control segmentation clock oscillations in mouse somitogenesis. Development 134: 4033-4041.

Wellik DM. 2007. Hox patterning of the vertebrate axial skeleton. Dev Dyn 236: 2454-2463.

White PH, Farkas DR, Chapman DL. 2005. Regulation of Tbx6 expression by Notch signaling. Genesis 42: 61-70.

Wilson V, Beddington R. 1997. Expression of T protein in the primitive streak is necessary and sufficient for posterior mesoderm movement and somite differentiation. Dev Biol 192: 45-58.

Wilson V, Manson L, Skarnes WC, Beddington RS. 1995. The T gene is necessary for normal mesodermal morphogenetic cell movements during gastrulation. Development 121: $877-886$.

Wittler L, Shin EH, Grote P, Kispert A, Beckers A, Gossler A, Werber M, Herrmann BG. 2007. Expression of Msgn 1 in the presomitic mesoderm is controlled by synergism of WNT signalling and Tbx6. EMBO Rep 8: 784-789.

Yamaguchi TP, Takada S, Yoshikawa Y, Wu N, McMahon AP. 1999. $T$ (Brachyury) is a direct target of Wnt3a during paraxial mesoderm specification. Genes Dev 13: 3185-3190.

Yang Y, Drossopoulou G, Chuang PT, Duprez D, Marti E, Bumcrot D, Vargesson N, Clarke J, Niswander L, McMahon A, et al. 1997. Relationship between dose, distance and time in Sonic Hedgehog-mediated regulation of anteroposterior polarity in the chick limb. Development 124: $4393-4404$.

Yasuhiko Y, Haraguchi S, Kitajima S, Takahashi Y, Kanno J, Saga Y. 2006. Tbx6-mediated Notch signaling controls somite-specific Mesp2 expression. Proc Natl Acad Sci 103: $3651-3656$.

Yoshikawa Y, Fujimori T, McMahon AP, Takada S. 1997. Evidence that absence of $W n t-3 a$ signaling promotes neuralization instead of paraxial mesoderm development in the mouse. Dev Biol 183: 234-242.

Zakany J, Kmita M, Alarcon P, de la Pompa JL, Duboule D. 2001. Localized and transient transcription of Hox genes suggests a link between patterning and the segmentation clock. Cell 106: 207-217. 


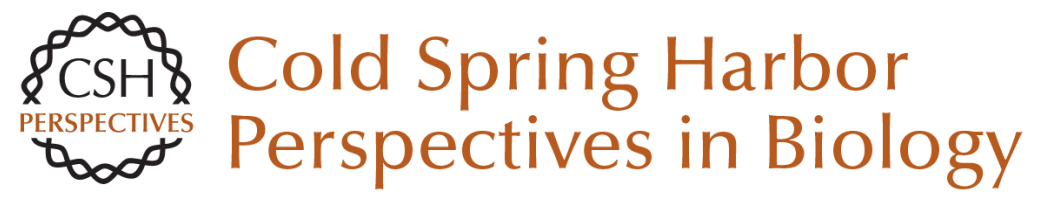

\section{Signaling Gradients during Paraxial Mesoderm Development}

Alexander Aulehla and Olivier Pourquié

Cold Spring Harb Perspect Biol 2010; doi: 10.1101/cshperspect.a000869 originally published online July 22, 2009

\section{Subject Collection Generation and Interpretation of Morphogen Gradients}

Regulation of Organ Growth by Morphogen Gradients

Gerald Schwank and Konrad Basler

Signaling Gradients during Paraxial Mesoderm

Development Alexander Aulehla and Olivier Pourquié

Morphogen Gradient Formation Ortrud Wartlick, Anna Kicheva and Marcos González-Gaitán

Nodal Morphogens Alexander F. Schier

Gradients and the Specification of Planar Polarity in the Insect Cuticle David Strutt

Vertebrate Limb Development: Moving from Classical Morphogen Gradients to an Integrated

4-Dimensional Patterning System Jean-Denis Bénazet and Rolf Zeller

Establishing and Interpreting Graded Sonic Hedgehog Signaling during Vertebrate Neural Tube Patterning: The Role of Negative Feedback Vanessa Ribes and James Briscoe

Systems Biology of the Self-regulating Morphogenetic Gradient of the Xenopus Gastrula Jean-Louis Plouhinec and E. M. De Robertis
Gradients in Planarian Regeneration and Homeostasis

Teresa Adell, Francesc Cebrià and Emili Saló

Shaping Morphogen Gradients by Proteoglycans Dong Yan and Xinhua Lin

Forming Patterns in Development without Morphogen Gradients: Scattered Differentiation and Sorting Out

Robert R. Kay and Christopher R.L. Thompson

Robust Generation and Decoding of Morphogen Gradients

Naama Barkai and Ben-Zion Shilo

Models for the Generation and Interpretation of

Gradients Hans Meinhardt

Graded Dorsal and Differential Gene Regulation in the Drosophila Embryo Gregory T. Reeves and Angelike Stathopoulos

Chemical Gradients and Chemotropism in Yeast Robert A. Arkowitz

Gradients in the Brain: The Control of the Development of Form and Function in the Cerebral Cortex

Stephen N. Sansom and Frederick J. Livesey

For additional articles in this collection, see http://cshperspectives.cshlp.org/cgi/collection/

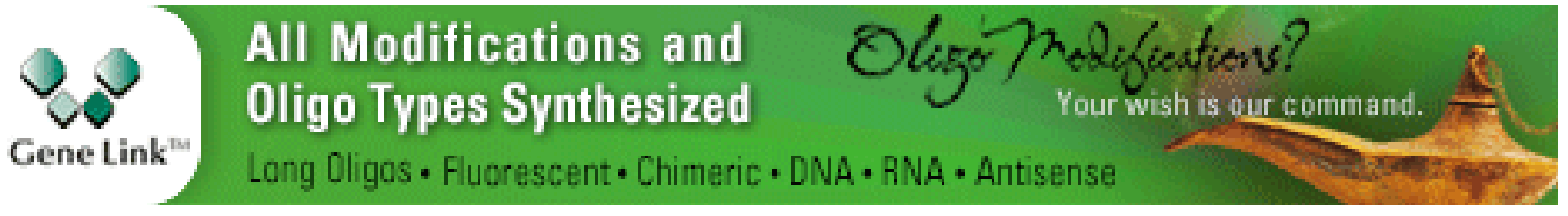


For additional articles in this collection, see http://cshperspectives.cshlp.org/cgi/collection/

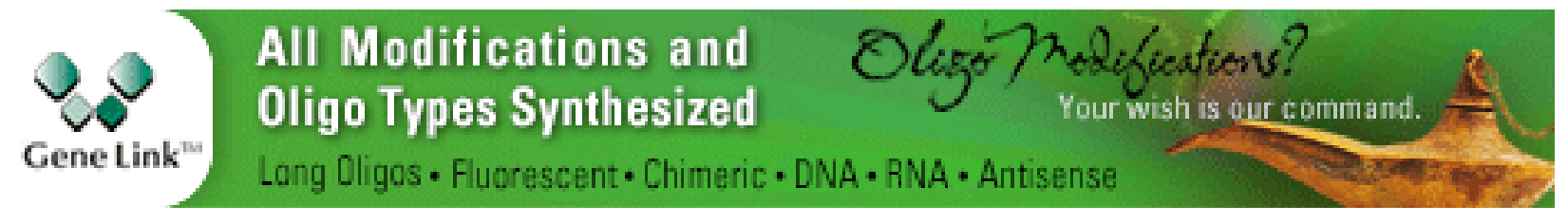

Copyright @ 2010 Cold Spring Harbor Laboratory Press; all rights reserved 